\title{
The birth of the memory of Communism: memorial museums in Europe
}

\author{
Máté Zombory* \\ Centre for Social Sciences, Hungarian Academy of Sciences, Budapest, Hungary
}

(Received 15 November 2016; accepted 31 May 2017)

\begin{abstract}
This article argues that the memory of Communism emerged in Europe not due to the public recognition of pre-given historical experiences of peoples previously under Communist regimes, but to the particularities of the post-Cold War transnational political context. As a reaction to the uniqueness claim of the Holocaust in the power field structured by the European enlargement process, Communism memory was reclaimed according to the European normative and value system prescribed by the memory of the Holocaust. Since in the political context of European enlargement refusing to cultivate the memory of the Holocaust was highly illegitimate, the memory of Communism was born as the "twin brother" of Holocaust memory. The Europeanized memory of Communism produced a legitimate differentia specifica of the newcomers in relation to old member states. It has been publicly reclaimed as an Eastern European experience in relation to universal Holocaust memory perceived as Western. By the analysis of memorial museums of Communism, the article provides a transnational, historical, and sociological account on Communism memory. It argues that the main elements of the discursive repertoire applied in post-accession political debates about the definition of Europe were elaborated before 2004 in a panEuropean way.
\end{abstract}

Keywords: European enlargement; memorial museums of Communism; memory of the Holocaust; transnational politics of memory; post-Cold War period

Studies applying a transnational perspective conceptualize European politics of memory as a struggle between two competing parties, each representing a specific vision of European history. Their point of departure is an uneven recognition of European memories, that is, an imbalance between the memory of the Holocaust and that of Communism. From a normative standpoint, these studies presuppose and encourage an ideal situation in which the memory of Communism will be acknowledged equally to that of the Holocaust (Assmann 2011; Gliszczyńska-Grabias 2016; Mälksoo 2014). In this perspective, the political struggle of European actors aiming at criminalizing Communism is theorized as a rightful attempt that "calls for recognition of the value of the distinctly East European experience that has not been universally shared in Europe" (Mälksoo 2014, 89). The basis of this "recognition-seeking campaign" is that all victims of past injustice deserve equal respect, irrespective of the causes of their suffering.

*Email: matezombory@yahoo.com 
This thesis of a "politics of recognition" has two unreflective features. The first is a direct causal link between history and politics: the past determines regional difference, which automatically calls for public recognition. Seeking reconciliation between competing visions of history, the thesis of politics of recognition mistakes the memory claims of the actors for history. Similarly to the "oracles of memory," supporters of the thesis tend to "celebrate the anti-historical component of memory; they claim that memories retrieve experiences that must remain ineffable" (Maier 1993, 143). The second unreflective feature concerns the Eastern nature of Communism: an experience directly known only in the Soviet member states and satellite countries. In this view, the memory of Communism in its currently canonized form is the outcome of a bottom-up process through which the Eastern experience of Europe has finally been (partially) acknowledged aside the founding experience of the Holocaust.

This article will criticize these premises of the politics of recognition thesis by focusing on the history of Communism memory since 1989. From a sociological perspective, it situates this history in the post-Cold War transnational space of politics, in which actors repositioned themselves as a reaction to geopolitical restructuration. This political space, a field of positions organized by memory claims, has two characteristics.

The first is the power relations generated by the enlargement process. The debate about Europe took place between two sides with unequal resources: European organizations and countries aspiring for membership in those organizations. According to the social vision of the first, former Eastern Europe was to be reintegrated into the continental civilization based on its universal values. In the ideological vacuum triggered by the definitive defeat of the Cold War enemy, the EU began to embrace the global Holocaust discourse (Calligaro 2015; Probst 2003): it localized (Zombory 2012) the deterritorialized memory of the Holocaust as a par excellence European historical experience, with universal significance. By the end of the 1990s, the universal moral message of Holocaust memory has become a constitutive part of the promotion of European norms and values. At the same time, models of reconciliation (Jouhanneau and Neumayer 2014) were developed that were supposed to appease social tension around competing interpretations of the past, and provide solidarity among actors with different visions of history. The principal model of reconciliation has become the integration of different memories into a common framework (based on canonized Holocaust memory) allowing solidarity based on commonly shared values, and the public recognition of the historical suffering of victims. The cultivation of Holocaust memory became, by the second half of the 1990s, a "soft membership criterion" to the EU (Leggewie 2010).

The social vision of the other side was quite different. Former Communist countries had to prove that they shared European norms and values and were thus mature enough to enter its political institutions. Incapable of influencing the criteria of their accession, they relied even more heavily on symbolic resources in the uneven political field of enlargement. In the early 1990s, they positioned themselves as already Western nations, previously "kidnapped by the East" (Kundera 1983) and now returning to Europe. By the end of the decade, however, their strategy changed because of the new integration policy of Europe, based on the memory of the Holocaust. The memory of Communism, as will be argued in this article, is the result of this transnational interaction of norms of historical representation.

The other feature determining the relations in the power field of European politics is victims' competition (Chaumont 1997; Maier 1993; Novick 1999). This structural dynamic is provoked by the uniqueness claim of the Holocaust, challenged by competing claims of past suffering. Two sides crystallize in the conflict: one charges the other with relativizing the Holocaust, and is in turn accused of the denial of recognition of other victims of political violence. In the discursive field of memory claims, victim status is 
legitimized by the accumulation of symbolic capital, that is, prestige, measured by the extent of human suffering. Memory tends to be sacralized (Todorov 1995, 2000), as actors strive to monopolize the principles of historical representation. Politics follows the "rules of the game," that should be respected as a precondition of participation. At the same time, taking up a position in the field involves the possible change of the rules (Bourdieu 1985).

The particularity of the European memory competition, in relation to earlier ones, was that definition struggles unfolded over a primarily geographical vision and division of the social world. Since the EU enlargement meant the change of existing political borders, the debate on the meaning of Europe reached far beyond the sphere of the symbolic. The reconstitution of Europe's past inherently involved the tracing of political boundaries of Europe both as idea and as geographical space. Accordingly, the spatial aspect of post-Cold War repositioning constitutes an important element of the following study.

This paper argues that the emergence of a memory of Communism and its later European canonization is due to the repositioning process in transnational political space. It will prove that the "historical experience" of Communism as presented in the literature on the "politics of recognition" is the outcome of the historical process through which, by the end of the 1990s, anti-Communist discourse was reformulated according to the prevailing European norms of historical consciousness. Communism as the Eastern experience of Europe was born in relation to the universal memory of the Holocaust, perceived by the actors as Western.

The empirical verification of the "politics of positioning" thesis elaborated here poses some difficulties. Current studies usually conceptualize transnational politics as the space of European political institutions, and thus focus on post-accession memory discourses. Before the accession in 2004-2006, however, political actors of the post-Communist countries did not take part in the decisive European organizations, yet they constituted part of the transnational space of politics defined above. As a reaction to the lack of institutional resources in transnational politics, new institutions were created in the associated countries, such as historical commissions, institutes of national memory, and museums of Communism, in hopes of shaping the continental debate. The main methodological difficulty is that this institutional landscape is diverse, scattered, and embedded in the national contexts. In what follows, I will empirically analyze the discourse about Communism by examining memorial museums, because these are historically the first institutional manifestations of the commemoration of Communism.

From a range of museums across the European Union, I considered those which exhibit Communism in an explicit way - that is, that dedicate their existence to this cause. From these, I selected those having an additional commemorative function besides that of historical representation (see Table 1). I consider memorial museums of Communism as institutionalized claims taking up a position in transnational political space: they reclaim the supposedly forgotten memory of Communism, in relation to the memory of the Holocaust. Museums that, though memorial, display only one aspect of Communism (such as the "Runde Ecke" Memorial Museum and Stasi Bunker Museum in Leipzig, Germany), or exhibit Communism without performing a memory claim (the DDR Museum in Berlin, for instance) are excluded from the scope of this research. Though empirically focusing on museums, the object of this study is the changing discourse on Communism. I will analyze this discourse using diverse primary sources on the museums (direct observations, inauguration speeches, journal articles, exhibit catalogs, official websites) and secondary data analysis (case studies on each selected institution). Instead of providing detailed analyses of each exhibition, this study aims at explaining the emergence of a specific vision of Communism by putting the cases into a wider transnational, historical, and sociological context. 
Table 1. Memorial museums of Communism in the EU.

\begin{tabular}{|c|c|c|c|c|}
\hline $\begin{array}{l}\text { Year of } \\
\text { opening }\end{array}$ & Name of museum & Principal initiator & $\begin{array}{l}\text { Background institution } \\
\text { (date of creation) }\end{array}$ & Location \\
\hline 1992 & $\begin{array}{l}\text { Museum of } \\
\text { Genocide Victims }\end{array}$ & $\begin{array}{l}\text { Union of Political } \\
\text { Prisoners and } \\
\text { Exiles }\end{array}$ & $\begin{array}{l}\text { The Genocide and } \\
\text { Resistance Research } \\
\text { Center of Lithuania } \\
\text { (1997) }\end{array}$ & $\begin{array}{l}\text { Vilnius, } \\
\text { Lithuania }\end{array}$ \\
\hline 1993 & $\begin{array}{l}\text { Museum of the } \\
\text { Occupation of } \\
\text { Latvia }\end{array}$ & $\begin{array}{l}\text { Paulis Lazda } \\
\text { (American- } \\
\text { Latvian history } \\
\text { professor) }\end{array}$ & $\begin{array}{l}\text { Occupation Museum } \\
\text { Foundation (1993; } \\
\text { now Association) }\end{array}$ & Riga, Latvia \\
\hline 1993 & $\begin{array}{l}\text { Sighet Memorial for } \\
\text { the Victims of } \\
\text { Communism and } \\
\text { the Resistance }\end{array}$ & $\begin{array}{l}\text { Ana Blandiana } \\
\text { and Romulus } \\
\text { Rusan } \\
\text { (dissident poet } \\
\text { and writer) }\end{array}$ & $\begin{array}{l}\text { Civic Academy } \\
\text { Foundation (1994) }\end{array}$ & $\begin{array}{l}\text { Sighetu } \\
\text { Marmatiei, } \\
\text { Romania }\end{array}$ \\
\hline 2001, 2003 & $\begin{array}{l}\text { Museum of } \\
\text { Communism } \\
\text { (under } \\
\text { construction) } \\
\text { (temporary } \\
\text { exhibition) }\end{array}$ & $\begin{array}{l}\text { Czesław Bielecki } \\
\text { (architect, } \\
\text { dissident) }\end{array}$ & $\begin{array}{l}\text { SocLand Foundation } \\
\text { (1999) }\end{array}$ & $\begin{array}{l}\text { Krakow, Nowa } \\
\text { Huta, Lodz, } \\
\text { Warsaw, } \\
\text { Poland }\end{array}$ \\
\hline 2002 & $\begin{array}{l}\text { House of Terror } \\
\text { Museum }\end{array}$ & Government & $\begin{array}{l}\text { Public Foundation for } \\
\text { the Research of } \\
\text { Central and East } \\
\text { European History } \\
\text { and Society (1999) }\end{array}$ & $\begin{array}{l}\text { Budapest, } \\
\text { Hungary }\end{array}$ \\
\hline \multirow[t]{2}{*}{2003} & $\begin{array}{l}\text { Museum of } \\
\text { Occupations }\end{array}$ & $\begin{array}{l}\text { Olga Kistler-Ritso } \\
\text { (American- } \\
\text { Estonian ocular } \\
\text { surgeon) }\end{array}$ & $\begin{array}{l}\text { Kistler-Ritso Estonian } \\
\text { Foundation (1998) }\end{array}$ & Tallinn, Estonia \\
\hline & $\begin{array}{l}\text { Memorial Museum } \\
\text { for the Victims of } \\
\text { Communism }\end{array}$ & Government & $\begin{array}{l}\text { The Institute for } \\
\text { Investigating } \\
\text { Communist Crimes } \\
\text { and the Memory of } \\
\text { the Exile (2005) }\end{array}$ & $\begin{array}{c}\text { Râmnicu Sărat, } \\
\text { Romania }\end{array}$ \\
\hline
\end{tabular}

In the following, I will first explore the historical knowledge production related to the museums; second, I will discuss their initiation, particularly the role of the state in embracing commemorative anti-Communism by the end of the 1990s; third, I will look at the way European norms of historical representation are applied in the exhibitions; and finally, fourth, I will discuss the significance of the museum sites in post-Cold War transnational repositioning.

\section{The pan-European origins of historical revisionism}

Museums of Communism make up part of a larger institutional infrastructure whose activities reach far beyond the museographic representation of the past. One such activity is historical knowledge production, which I analyze here in terms of the sources and the network of actors. The source of historical knowledge that museums of Communism transmit is not an authentic East European experience, but a body of West European literature. Museums of Communism constitute part of a pan-European discourse and build on networks of 
historical revisionism, aiming to produce a legitimate anti-Communist vision of history. Through these sources and networks, anti-Communist circles in the former Eastern Bloc have not only been aware of recent and ongoing European debates over the historical legacies of the twentieth century but cooperated directly with their Western colleagues. These east-west channels enabled the successful transmission of the vocabulary and argumentative repertoire of European anti-Communist historical revisionism into the national contexts of the associative countries.

\section{Sources of history}

Though the anti-Communist critique of totalitarianism originates in the 1950 s and had its historical moment in the 1970s (Christofferson 2004), it gained continental relevance with the dissolution of the bipolar world order. As a new characteristic, the emphasis shifted from scholarly interventions to performing a memory claim. From the mid-1990s historical revisionism, besides scholarly research, increasingly operated in a moral tone positioning itself in relation to the cult of Holocaust memory. In 1997, French historian Alain Besançon delivered a lecture at the Institut de France, under the title "Memory and Oblivion of Bolshevism," in which he argued that the victims of Communism needed the same degree of recognition as those of the Holocaust, and that Nazism and Communism were equally criminal (Besançon 1998, 155-163). Besançon, who tried in his related book (1998) to assess the historical role of Communism by using the model Raul Hilberg had elaborated for the Holocaust in The Destruction of the European Jews (1985), introduced the influential opposition between the hypermnesia of Nazism and the amnesia of Communism. The historical and memorial canon of the Holocaust served as an example for the elaboration of a new vision of Communism. Besançon's influence is not merely indirect, since he, as a member of their honorary boards, is institutionally connected to the public foundation running the Hungarian House of Terror Museum and to the SocLand Foundation, the NGO founded in 1999 aiming at the creation of Poland's museum of Communism.

The publication of Le Livre Noir du Communisme: Crimes, Terreur, Repression in 1997, particularly the introduction of French historian Stéphane Courtois, made an even more significant impact. The book, despite the controversy it provoked (Aronson 2003), largely contributed to the legitimacy of juxtaposing Communism to Nazism as an equal, if not even more criminal and illegitimate system. Courtois's introductory piece, entitled "The Crimes of Communism," gives the quintessence of post-1989 anti-Communist historical revisionism. Communism, interpreted exclusively as a criminal, terroristic, and inhuman evil, appears in this discourse as an ahistorical and essential truth of history that has been denied. Courtois, similarly to Besançon, speaks of a "sharp contrast" $(1997,27)$ between the academic and public recognition of the crimes of Nazism and those of Communism. Providing the reasons for this imbalance, the historian constructs a detailed narrative of Great Occultation: even though there were several testimonies and scholarly works on the criminal nature of Communism, Courtois argues, the world, especially the West, "refused to face reality" and by this refusal, "it was co-conspirator in the lie" $(1997,36)$. The reasons given by Courtois for the alleged silence around the Truth of Communism that proved to be particularly influential in post-Communist circles are the following: Communism legitimized itself by revolutionary passion; the Soviet Union could gain legitimacy from participating in the victory over Nazism; and the ideology of antifascism could be reactivated by exploiting the fact that the Holocaust had become the image of the ultimate evil in history. 
The myth of contumacious silence that resists any kind of clarification provides moral legitimacy to the historical revisionist cause: the "suppressed" memory of Communism must be reclaimed, thus its truth disclosed, and the human dignity of victims restored. What is more, historical justice must be done, thus breaking Communism's continuous hold on the present. Courtois, like other proponents of the cause, finds the paradigm of historical justice in the Nuremberg trials that he - mistakenly - interprets as a reaction to the horrors of the Holocaust. The conclusion is that Communism also needs its own Nuremberg trials.

From the need for historical justice comes the changing role of the historian, who is driven not only by the "duty of history" to accumulate knowledge of whatever controversial and taboo historical phenomena, but also by the "duty of memory," a moral obligation to honor the memory of the innocent victims of an evil with omnipotent power. For Courtois, accordingly, the historian becomes the spokesperson of those who, because of the terror, were incapable of telling the truth about their conditions. The introduction even positions the Black Book as a contribution to the great European endeavor of reconstructing a common memory after the fall of the Berlin Wall.

Courtois's arguments made their way to post-Communist contexts in several ways. His estimation of 100 million victims of Communism against 25 million victims of Nazism $(1997,25)$ were presented, without the debate it triggered, as rock-solid historical evidence of Communism's criminality, sometimes even as a well-known fact, without indicating the source (e.g. Schmidt [1999] 2003b, 12). Courtois's impact on memorial museums of Communism was in many cases more direct: as a member of the scientific board of the International Centre for the Study of Communism, and rector of the annual Summer School organized by the Civic Academy Foundation, he personally cooperated with the actors involved in the Sighet Memorial Museum (Courtois 2003). In 2000, the 20th Century Institute, one of the two research institutions of the public foundation behind the House of Terror Museum, organized an international conference in Budapest on the Black Book, at which Courtois and other authors, together with Besançon, participated. The conference papers appeared in book form later that year, as did their Hungarian translation, though at a different publishing house. In 2005, the Polish History Meeting House staged the temporary exhibition "Two Faces of Totalitarianism: Twentieth Century Europe" in Warsaw, covering the Soviet and Nazi regimes from the end of the Great War until 1947, "the defeat of Nazism and the triumph of Communism." As Main observes $(2008,389)$, "the objective of the exhibition was the visualization of the thesis by Stéphane Courtois in the introduction to the Black Book of Communism: Crimes, Terror, Repression."

Besides that of Courtois and Besançon, German historian Ernst Nolte's work was also influential. In 2003, for instance, the 20th Century Institute published his Der Faschismus in seiner Epoche (1963) in Hungarian, and organized a public discussion around it in the presence of the author. The next day Nolte gave a lecture to the Hungarian public on the consequences of the 1986-1987 West German historians' controversy, in which he infamously suggested that the Final Solution, specific only in technical terms, was a selfdefending reaction to the Bolshevik program of extermination.

\section{Network of activists}

Scholarly contacts, whether bibliographical references or personal relationships, were not restricted to historians. International experts in other fields also played an important role in reclaiming the memory of Communism. American geostrategist, foreign relations expert and politician Zbigniew Brzezinski, former National Security Advisor to US 
President Carter, contributed a letter of support that was read out at the inauguration ceremony of the House of Terror Museum. He is member of the international advisory board behind the House of Terror, of the Directors of the Museum of the Occupation in Latvia and also, together with Besançon, of the honorary board to the SocLand Foundation.

Not only scholars were interested in reclaiming the memory of Communism in Europe. The role of politicians was essential, too. The Estonian edition of the Black Book appeared in 2000 with a preface by President Lennart Meri, and an additional chapter entitled "Estonia and Communism" authored by Prime Minister Mart Laar. The latter, by profession a historian, is a member of the international advisory board of the foundation of the House of Terror, which published his book in Hungarian. The role of politicians associated with memory museums of Communism who, becoming MEPs with the accession of their country, largely contributed to putting their cause on the European political agenda is also significant. József Szájer, whose idea it was to create the House of Terror Museum, Tunne Kelam, member of the board of the Kistler-Ritso Estonian Foundation, the organization behind the Museum of Occupations in Tallinn, and Sandra Kalniete, who is affiliated as a supporter with the Occupation Museum Association of Latvia, were all prominent figures in the European criminalization of Communism that culminated in the adoption of an EU resolution "on European conscience and totalitarianism" in 2009 (Neumayer 2015).

Finally, besides scholars and politicians, eminent former dissidents also took an active part in the pan-European effort to reclaim the memory of Communism. The most important is the former Soviet dissident and human rights activist Vladimir Bukovsky, who did so as a member of the Scientific Council associated with the Sighet Memorial Museum in Romania, and on the international advisory board to the foundation running the House of Terror Museum. Bukovsky's Judgement in Moscow (1995) is a reference work in this circle with respect to the "missed Nuremberg" for Communism (cited also by Courtois's introduction). Another important figure of the anti-Communist dissidence is Polish architect and politician Czesław Bielecki, the initiator and first director of SocLand Foundation. In 2003, Bielecki's foundation organized a temporary exhibition on Communism in Warsaw, with the cooperation of the 20th Century Institute (Bielecki 2003). As a member of the international advisory board, Bielecki is affiliated with the House of Terror in Budapest.

In sum, reclaiming the memory of Communism was the cooperative effort of a panEuropean network of activists, scholars, and politicians engaged in the struggle for a legitimate anti-Communist revision of history. Their historical revisionism is characterized by its memorial-moral nature. The reference point of their memory claim was not lived history, but the universal memory of the Holocaust. Seemingly challenging the uniqueness claim, this performative argument in fact follows the pattern of reclaiming the memory of the Holocaust (Rousso 2011, 237). It relies on the imperative of "Never again!" and on the vocation to restore the dignity of Communism's victims. Commemorating their past suffering is justified by the need to avoid the repetition of the traumatic past. The discursive alchemy of reclaiming Communism memory turns a particular interpretation of Communism into a memory with eternal truth and a moral lesson, which is well received because of the European modalities of its creation. As in the case of the Holocaust, the memory of Communism has been detached from lived historical experiences and become an abstract, even mythic image of evil in history.

\section{Europeanizing Communism}

Because of the interaction of the actors in transnational politics, the discourse on commemorating Communism considerably changed by the end of the 1990s. I will demonstrate this 
transformation in terms of the references to the Holocaust, with particular attention to the role of the state.

\section{The uniqueness claim of Communism}

The "first wave" of memorial museums of Communism, those in Vilnius, Riga, and Sighetu Marmatiei, were initiated by sub-state political activist forces, composed of anti-Communist political diaspora, and domestic dissidence. Early promoters of Communism memory made direct references to the Holocaust from the beginning. The "success story" of the Jews in condemning Nazism by making an internationally recognized symbol of their suffering was presented as the path to follow. ${ }^{1}$ They usually pressed the necessary elaboration of Communism as a symbol of evil, which would be attained in a similar manner as in the case of the Holocaust. This mission was taken up by the Museum of Genocide Victims, instigated by the Union of Political Prisoners and Exiles, that exhibits Soviet repression as the deliberative attempt of genocide against the Lithuanian nation (Mark 2008).

The Museum of Occupations in Riga also took the vocation to show the world how the Latvian nation suffered under Soviet occupation. Its permanent exhibition, opened in 1993, "presented and explained the atrocities of the Soviet regime in Latvia 1940/41," and was expanded in the following years "to include the entire occupation period," that is, 1940$1991 .^{2}$ Communism as a unique historical experience remained the message, despite the fact that a creator and first director of the museum, an American-Latvian history professor who left the Baltics in 1944, created a museographic concept that deals with both the Nazi and the Soviet occupations. The exhibition separated the Holocaust from national history, and thus presented a far less severe Nazi occupation than the Communist one. Even in this way, the main initiator met some local difficulties in incorporating the Holocaust into the exhibition, and the Latvian political elite began to acknowledge the mission of the museum only by the late 1990s when it embraced the idea of "double genocide" (Mark 2008).

One of the founders of the Sighet Memorial Museum, Ana Blandiana, stated in 1996 that the idea of the institution came after a visit to Auschwitz:

Why not think about undertaking a twin center of research on Communism?, we asked ourselves. Why not suggest a larger and more complex outlook on the two types of suffering endured by the Europeans in this century? Why not accept a parallel between the two types of totalitarianism? (Quoted in Laignel-Lavastine 2004, 174)

The desired acknowledgement of the anti-Communist cause refers to the analogy between the two types suffering under different totalitarian regimes. In Romania too, the main political intention of anti-Communist circles was to get the "Red Holocaust" acknowledged internationally in order to legitimately condemn Communism as even more criminal than Nazism. As journalist Roxana Iordache argued in her article entitled "The other Holocaust" in 1993,

If the entire world today condemns Nazism to the point of continuing the search for those who served it, it is impossible to explain why the same thing is not being undertaken in regard to Communism. [...] Nevertheless, the survivors of Hitler's camps who were later thrown into Communist prisons, claim that these were much harsher. (Quoted in Laignel-Lavastine 2004, 174)

This argument points to the lack of a European memory discourse in early post-Communist anti-Communism. The emphasis is put on survivors' capacity of witnessing and not on the moral obligation to respect the suffering of innocent victims. As a consequence, the idea of 
equal criminality grounded by the equal respect of past suffering is lacking from the argumentation. "The same thing" demanded by the author refers not to the suffering of the victims but to the legitimacy of condemning Communism and pursuing its collaborators. Moreover, the desired future status of Communism as "another Holocaust" (or "Soviet genocide" in the Baltics) is unique; Communism is not put in the same framework with the Holocaust - instead, the effective international condemnation of Nazism is used as analogy. Consequently, commemorating the Holocaust is not "our duty."

The construction of "our type of suffering" was eventually deeply influenced by the representational canon developed in Europe in the 1990s. During this transformation, antiCommunist discourse on memory lost its confrontational and exceptionalist nature and began to be "Europeanized," that is adjusted to the prevailing norms of historical memory and reconciliation. Instead of presenting its uniqueness in the history of political violence, the memory of Soviet repression was put into a common framework with the Holocaust, which was presented as the constitutive European experience. This meant that the relation of the two memories acquired a central significance in political struggles, and refusing the importance of cultivating Holocaust memory became highly illegitimate.

\section{National suffering under double occupation}

It happened to be decisive that, by the end of the 1990s, post-Communist states, eager to meet European expectations to "coming to terms with" their totalitarian pasts, began to take up positions in the discourse of commemorating Communism. This resulted in the "second wave" of museums, established or encouraged by governments. In the Baltic states, due to international pressure to commemorate the Holocaust, the conflict was consolidated by state efforts to "reconcile" Jewish and national suffering, which resulted in the official terminology of "double occupation" (Budryte 2005, 184-186) and the strategy of comparison, that is, displaying the Holocaust in order to picture the degree of suffering under Soviet occupation (Bonnard and Meckl 2007). In 1998, the three Baltic presidents initiated the formation of national commissions of historians to study the crimes against humanity of both Nazism and Communism (Onken 2007). The work of the commissions, which included acknowledged political figures and Western experts, aimed to legitimize the construction of Communism memory as a criminal system while avoiding international criticism for relativizing or marginalizing the Holocaust. The strategy of juxtaposing the Jewish and the national genocide was the outcome of this "reconciliation process."

The Museum of Occupations in Tallinn is a private initiative that was fully embraced by the state. At the inauguration ceremony in 2003, the main initiator of the institution, Estonian-American dissident, and ocular surgeon Dr Olga Kistler-Ritso, who had fled in the face of the Red Army in 1944, cut through barbed wire, and state representatives gave speeches at the site. ${ }^{3}$ Estonia's then-Prime Minister, Juhan Parts, called the institution "a museum where we can see what once was, but shall never be repeated." Lennart Meri, president of Estonia (1992-2001) and patron of the American Kistler-Ritso Estonian Foundation, spoke of the site as expressing "Our existence, our historical experiences, the quarter of the Estonian population that we mourn here, whom we lost." Tunne Kelam, member of the Board of the Kistler-Ritso Estonian Foundation, also contributed to the sacralization of the site when paying respect to "those tens of thousands of people whose sufferings have been recorded here," and added, "It is for them that this building was erected in order to memorialize the collective tragedy experienced by the Estonian people." Kelam, who from the next year was MEP in the EPP Group, emphasized in his inauguration speech that "The crimes of the German National Socialist regime have been condemned 
authoritatively and universally, while the Soviet Communist regime's equally reprehensible crimes and the genocide carried out on Estonian territory and elsewhere have not been fully analyzed or judged." The state-supported political agenda was clearly defined as adjusting this imbalance in European memory.

In 2003, Romanian president Ion Iliescu, under international pressure, initiated the International Commission for the Study of the Holocaust, chaired by Elie Wiesel. Its report, presented on 12 October 2004, the Holocaust Memorial Day in Romania, evoked little public response. This was not the case with the final report of the Presidential Commission for the Analysis of Communist Dictatorship, initiated by president Traian Băsescu in 2006, and chaired by Vladimir Tismăneanu, renowned American political scientist of Romanian origin. This report provided a scientific basis for the president to officially condemn Communism as illegitimate and criminal. Members of the Civic Academy Foundation, the NGO behind the Sighet Museum, took an active role in the work of the commission. It was the report of this historical commission that recommended creating a Museum of Communist Dictatorship that, "like the Holocaust Memorial in Washington, would be both a place of memory and an affirmation of the values of the open society" (quoted in Bădică 2013, 113). Râmnicu Sărat, a former prison, was chosen as the site of the Memorial Museum for the Victims of Communism, as the museum was ultimately named (Bădică 2013). The Institute for the Investigation of Communist Crimes and the Memory of Romanian Exile, the organization responsible for the creation and maintenance of the new museum, was founded by the government in 2005.

In Hungary, where there was neither a historical commission nor (until recently) an institute of national remembrance, the government created the Hungarian Public Foundation for Research on Central and East European History and Society in 1999, with the task of operating a museum. The exhibition at the House of Terror was eventually created according to the theory of double occupation. As Prime Minister Viktor Orbán said in his inauguration speech in 2002, "We locked two dictatorships together within the walls of this house. They stem from different sources, but you can see, they get on well with each other." ${ }^{4}$ He presented Communism as one of the two foreign dictatorships under which the Hungarian nation suffered.

For existing memorial museums, governmental engagement in the discourse on Communism memory did not necessarily mean the state's full-scale institutional commitment, as it did for the Museum of Genocide Victims from 1997. But they could now count on a more favorable political environment for their activities. In line with the transformation of the discourse on Communism, museums of the "first wave," which managed to finalize their main exhibitions by the end of the decade, gradually changed exhibition strategies. In the beginning, the display at the Sighet prison was limited to three cells, in which only those objects were exhibited that were "originally" found there. After 1997, when the prison museum turned into the Museum of the Victims of Communism and Resistance and was given the status of "ensemble of national interest" (Bădică 2013; Cristea and Radu-Bucurenci 2008), the exhibition was no longer directly connected to the site and the individuals who had suffered in the prison: it became the metonymic symbol of national suffering. In 2000, the restoration of the prison building ended; since then the actual permanent exhibit "proposes a global discourse on Romanian communism" (Bădică 2013, 280).

In sum, the "Europeanization" of the memory of Communism meant the application of the prevailing norms of historical consciousness, with the memory of the Holocaust in its center. The main driving force behind the change of early anti-Communist discourse was that the state, as part of its endeavor to prove its "Europeanness" in transnational politics, embraced memorialist anti-Communism. Consequently, Communism memory appeared at 
the end of the 1990s as the identical counterpart of Nazism. As historian Péter Apor aptly put it $(2012,574)$,

The depiction of communism solely as a terror regime conspicuously next to the already established icon of violence, Nazism, is an attempt to transform the Gulag into a counter-Auschwitz, to construct an understanding of the history of communism as the twin of the ultimate horrors of Nazism and as the Eastern double of the ultimate catastrophe of European civilization.

The construction of this relation is based on the ideology of totalitarianism, presenting both systems as essentially characterized by terror and crime, in sharp opposition to today's democracies. In the political space of comparison, which is in fact the space of competition, the diverse historical experience of decades of existing socialisms is transformed into a uniform historical trauma. The memory of Communism is presented as just as unimaginable as the Holocaust, and also as detached from the historical complexity of the Second World War. What can be debated, then, is the degree of human suffering caused by the two evils.

\section{Staging the evils of history}

Exhibitions of Communism memory make visual the pan-European discourse of antiCommunist critique of totalitarianism when presenting Communism in an abstractmythological context. It appears as an evil of history that can be identified in sharply different historical periods and geographical sites. The exhibition concept of SocLand Foundation, in an exemplary fashion, illustrates the history of Polish Communism with horrific pictures from the Soviet gulag and the Chinese Cultural Revolution. The exhibition catalog does not even mention the two world wars, thus representing Communism as a blow of fate, the consequence of the mere monstrosity of Communists. It shows the installation of the system as the consequence of foreign imposition from above on the innocent population. The fact that "Poles, just like other subjugated nations, fell into the trap of history," hindered their social and economic development vis-à-vis the West, such as in the case of other "countries starting from a similar level right after the war" (Bielecki 2003, 36). This astonishing statement not only claims that in the 1940s eastern European countries were at the same social and economic developmental level with the West, but also that their present-day drawback is exclusively due to Communism.

Communism and Nazism are related in this abstract space of exhibition. The visual representation of the "double occupation," by spatially juxtaposing Nazism and Communism, synchronizes the two as evils of history, concealing their historically successive and antagonist relation (see the House of Terror Museums' first exhibition hall; Schmidt 2003c). This synchronic spatial juxtaposition is usually realized by using the iconic symbols of historical horror, the Holocaust (see the use of boxcars, the pile of suitcases, and the political symbols at the exhibition of the Museum of Occupations in Tallinn; Burch and Zander 2010). The displays rely on the technology of visual representation of the global Holocaust memory (Goldman 2006; Linenthal 2001; Macdonald 2013). In the following, I look at how the repertoire of museographic Holocaust representation is applied in memorial museums of Communism. I focus on three key aspects: personification, narrative enactment, and the role of objects.

\section{The archive of the victims}

Similar to memorial museums of the Holocaust, exhibitions of Communism carry a moral mission of commemorating past suffering of victims in order to avoid the repetition of historical trauma. An important feature here is the personalization of history - that is, 
presenting the past through individual stories and from the perspective of the victim. In Holocaust museums, the emotional identification with the suffering victims is supposed to foster moral engagement to fight against intolerance and anti-Semitism. Thus, the significance attributed to photos and video recordings of victims, the most famous examples being the Hall of Names at Yad Vashem and the Tower of Faces at the USHMM. Presenting the victims' photos is a popular technique of representation in memorial museums of Communism. On the walls of the inner courtyard of the House of Terror, the museum presents the faces of 3500 victims of both the fascist Arrow Cross and the Communist terror; however, in sharp contrast with the Tower of Faces, it uses the standardized "mug shot" photos of individuals without any information about them, or the possibility to "browse" the collection. The personal history of the victims is left obscure, and the fiction of standardization coming from the display suggests that what is seen is a singular registry, in which the faces do not stand for themselves but "appear as documents, as evidence of the two terror regimes' common archive" (Rényi 2003).

\section{Revenge on the perpetrators}

An essential museographic strategy fostering identification with the victims is narrative enactment. Weinberg (1994), who oversaw the final design of the Holocaust Memorial Museum in Washington DC, emphasized in this respect that narrative museums, unlike collection-based ones, invite visitors to internalize the moral lessons of history through ensuring emotional involvement in the narrative plot. In the Sighet Memorial Museum, for instance, the stages of the historical narrative are displayed in the prison cells.

The museum exhibits a teleological understanding of the communist regime: from the original sin, namely forged elections, the subsequent crimes of repression and terror followed logically up to Ceausescu's cult of Power, ending in the emergence of resistance and the victory of anticommunism. (Cristea and Radu-Bucurenci 2008, 301)

Visitors to the House of Terror start their pilgrimage-like trajectory at the top floor, and after a downward immersion in Inferno, they end it after having passed through the basement with the cellars, where a torture chamber of the Communist secret police has been reconstructed (Schmidt 2003c).

By narrative enactment, visitors are invited to live through history "as it happened" from the perspective of its victims. At the same time, according to the social categorization of Holocaust memory, they are also supposed to have elaborated emotions and moral judgement towards the perpetrators. This has an important political aspect, since by transmitting the "duty of memory" museums address problems of the present. Unlike anti-Semitism, the main present-day target of Holocaust museums, museums of Communism act upon the alleged Communist remnants of the past. The Sighet Memorial Museum, according to Blandiana, aims to point to Communist crimes' "residues in the society of a Euro-Atlantic integrated country" (Bădică 2013, 283-284). The "Perpetrators' Gallery" at the end of the House of Terror's exhibition trajectory displays the photographs, names and dates of birth, and death of former members of the state security service between 1945 and 1956. The fact that many of the persons identified as perpetrators are still among the living (only their date of birth is indicated) points to the specific political role its creators attributed to the institution. This role far exceeds the factual transmission of historical past, as it intends to contribute to the trials of the persons exhibited as perpetrators of Communism. If the public recognition of "Communist crimes" as crimes against humanity, having no statutory limitation, fails, then what remains is the possibility of moral condemnation. As the professional director of the House of Terror, one of its founders, stated, the institution accuses and 
condemns all employees of the former secret police, using the Nuremberg Trial as a model. Since, because of the statutory limitations, judicial trials would not be possible in terms of present-day laws, he said, the task falls on historians to morally avenge the victims (Gergely 2002).

\section{Objectivity without objects}

One reason why we cannot consider museums of Communism as embodiments of the global museographic trend of shifting from object to experience (Hein 2000) is that they detach objectivity from objects. It is very telling that the only collection-based exhibition of Communism in the region, the one that opened in Prague in 2001, is an apolitical touristic enterprise of an American businessman, rather a cabinet of Communist curiosities than a museum (Akinsha 2006). Institutions reclaiming the memory of Communism are characterized by the lack of authentic objects. The representative of the Museum of Occupations in Tallinn spoke of a "small but rapidly growing" collection, ${ }^{5}$ while the one of the Riga museum mentioned the "deficit of "3D material"" (Denis 2011) and the SocLand Foundation tried to obtain objects to exhibit by such campaigns as the one "Bring Communism to the Museum" in summer 2005. The deficit in legitimacy caused by this "objectless objectivity" in the display is partly compensated by the historical knowledge production associated with the museums. Bodies of research assume a significant role of producing authenticity by providing historical evidence through internationally legitimate methods of research: collecting witness testimonies and photographs, conducting oral history research, but also organizing conferences, international networking, often in the regional "alternative infrastructure" of government-initiated institutions of scholarship.

At the same time, the lack of authentic objects reduces the constraints on fabricating historical experience - all the more so, in that it is coupled with an authoritative attitude towards the display. Unlike in cases of museums on the move from object to experience, memorial museums of Communism exclude the audience from contributing to the concept of exhibition and deprive them of the possibility to explore subjective but authentic experiences. Though the House of Terror, for instance, displays some objects authentic to the site in particular and to the subject of the exhibit in general, it obscures the boundary between the different types of objects on display: authentic, fabricated/fake, and unclarified (Frazon and Horváth 2002). Thus, it creates a decontextualized exhibition space, in which objects are put on stage in a theatre-like installation, where meanings associating Communism with terror, crime, and violence can be almost freely fabricated. After all, authentic "objects of Communism," except for the few items of torture and violence, would evoke the everyday life experience in existing socialisms, which would definitely risk the ideologically preferred meaning construction of Communism as terror and crime. But most memorial museums of Communism do possess one unique object that can serve as the single source of authenticity for the entire exhibition: the site.

\section{The spirit of the place}

Countries at the gates of Europe did not simply adopt European norms of historical consciousness by establishing the cult of Holocaust memory in their national cultures. By re-appropriating these norms, they presented the memory of Communism as the additional specificity of their past. The localization of Communism as Eastern is clearly manifested in the memorial function of museums of Communism. 


\section{Sacralized sites}

The House of Terror Museum in Budapest opened in 2002 in a building that had served as headquarters of the Hungarian Nazi Arrow Cross party, which seized power on 15 October 1944, and subsequently as that of the state security forces, led by the Communist Party, until 1951. Created from the national budget, the museum was inaugurated by the Prime Minister two months before the general elections. Viktor Orbán, justifying the establishment of the institution by the "duty to remember," devoted his speech largely to the building. "This house is a memento. Living suffering," he said. The fact that the site deals with individual suffering and death turns the museum into a memorial, a site of mourning. To the criticism that the institution was created and opened as part of the political campaign of the ruling conservative party, the director of the institution, personal consultant of the prime minister at the time, replied that it had been created "in the memory of the suffering of a nation with the burden of history. We wanted to create a memorial to the victims;" those who project political intentions behind it "are incapable of paying tribute to the memory of the victims" (Schmidt 2003a, 179). Mária Schmidt argued that the House of Terror is supposed to foster common thinking about the last decades, so that "finally the work of mourning begins, the necessity of which is so incontestably described by our Nobelprize laureate, Imre Kertész, in relation to the Holocaust" (Schmidt 2003a, 185). The architectural innovations of the building, the rites of inauguration, and annual commemorations construct the House of Terror as a sacred site in the Durkheimian sense, dealing with the memory of the dead.

Besides the House of Terror, the Sighet Memorial, the museum at Râmnicu Sărat, and the Museum of Genocide Victims are all located at sites of suffering caused by political violence: former political prisons or political police headquarters. The Museum of the Occupation in Riga originally took the building that until 1991 housed the museum for the Latvian Riflemen, a group that supported the Bolsheviks during the Russian revolution and the ensuing civil war. Considerable efforts have been made to erase the ideologically undesirable reminiscence of the building's history (Mark 2008, 362-363), and a plan even surfaced to move the institution to the former building of the NKVD in Riga (Denis 2011).

The SocLand Foundation planned to establish the future museum of Communism in the cellars of the Palace of Culture and Science in Warsaw, built in 1952-1955 as a gift of the USSR to the Poles, dedicated to Stalin. Eventually, the permanent museum project was not successful; it has not been opened until today. In 2001 and 2003, the foundation organized a number of temporary exhibitions in Krakow, Nowa Huta, Lodz, and Warsaw. In the capital city, the cellars of the Palace of Culture hosted the show, deliberately relying on the "Disneyland effect." The catalog of the Museum of Communism actually does not show the building but instead "Stalin's shadow over Warsaw" (Bielecki 2003, 46): the impact of Stalin (and his "imported" Communism) on Warsaw, metonymically on all of Poland. Accordingly, the representation of Communism as an absurd and grotesque idea was subordinated to the emphasis on Communism as an alien and inhuman terroristic force imposed from above, brainwashing the innocent Polish people.

The creators of the Museum of Occupations followed a different path, launching an open competition of design for a new building in Tallinn. In this case, the new building's integration into the city acquired symbolic relevance, in the way it restructured the memorial landscape. According to Burch and Zander, the "Monument to the Liberators of Tallinn," commonly known as the "Bronze Soldier," was relocated to the Tallinn Military Cemetery at the outskirts of the capital city in 2007 , so as not to disturb the symbolism of the urban landscape. 
After its removal there is nothing left to interrupt the straight line of 'freedom' running from the Parliament to the Museum of Occupations and the nearby National Library. The presence of the Museum of Occupations thus explicates the absence of the Bronze Soldier. (Burch and Zander 2010, 60)

Though not located at the site of former political violence, the museum clearly acquires an additional function as a memorial. The DVD about its design and construction considers it as a "place of remembrance for those whose graves lie in places we are unaware of. The architects have integrated the memorial into the museum and into the city as such" (quoted in Burch and Zander 2010, 58-59). This is in line with the goals and objectives of the Kistler-Ritso Estonian Foundation to establish a museum that "would be a tombstone for the thousands of countrymen buried in anonymous graves." 6 Thus, this museum is also a sacred site of the dead, similar to the tombs of the Unknown Soldier. Its memorial function does not come from already commonly shared meanings but from the discourse and ritual action aiming to inscribe appropriate meanings to the materiality of the site.

\section{Communism as Eastern experience}

The localization of museum sites constituted a powerful source of authenticity. According to the myth of the genius loci, it is history itself embedded in the materiality of the buildings and sites. The sites of exhibition appear as "objective witnesses" of history, establishing the identity of past and present (the site left as it was used at the time of political violence). The symbolic significance of the "spirit of the place" might explain the otherwise rather ambiguous reconstruction efforts of former prison cells and execution chambers (Bădică 2013; Mark 2010; Sarkisova and Apor 2008). What is important here is that the main principle of producing authenticity at these sites is the primacy of the lived experience of the suffering victim. The "spirit of the place" is carefully orchestrated by historical periodization limiting the exhibition narrative to or focusing it on Communist terror and crime. At the same time, this limited aspect of the site's history is commemorated as a national experience. The displays extend the period of political violence to the whole of the state socialist period, disregarding the different usage of the site before and during Communist rule. It follows that the memorial site acquires the meanings of a crime scene, a wound on national soil where, according to the European vocabulary, human rights were severely violated by Communism.

The "spirit of the place" served as a powerful symbolic instrument of localizing the memory of Communism as Eastern in the transnational political space. For its promoters, the memory of Communism was far more than an aspect of the European past. Constructed on the model of the Europeanized memory of the Holocaust, it has become a legitimate historical experience what made "our place" in Europe specific and significant. The memory of Communism was born as an "Eastern European experience" in reaction to the universalist claim of the Holocaust (perceived as Western). Its cradle was not the lived history of peoples previously living under Communist rule, but the transnational power relations of the European enlargement process. This is why memorial museums, especially compared to claims referring to them, are so poorly embedded in the social life of their local and national environment. Estonians make up only $10 \%$ of the occupation museum's visitors (altogether approximately 1000 people in a year) ${ }^{7}$; in Riga, $75 \%$ of the annual 100 120,000 visitors are foreign tourists, and the majority of the local ones are students (Denis 2011). The House of Terror can be proud of welcoming half of its visitors from Hungary, but organized school class visits are included in this figure (Ablonczy 2012). The impact of these institutions is rather international, as they serve as points of reference 
for political claims in the European arena. Their local impact on historical consciousness is doubtful, considering the gap between the Europeanized memory construction of Communism and the diverse experience of local populations.

\section{Conclusion}

This article argues that the memory of Communism emerged in Europe due not to the public recognition of pre-given historical experiences of peoples previously under Communist regimes, but rather to the particularities of the post-Cold War transnational political context. As a reaction to the uniqueness claim of the Holocaust in the power field structured by the European enlargement process, Communism memory was reclaimed according to the European normative and value system prescribed by the memory of the Holocaust. As a consequence of adopting those norms, early post-Cold War anti-Communism, striving to legitimately condemn Communism in a similar way to how Nazism had been condemned by the negative image of the Holocaust, transformed into a memory discourse. By the end of the 1990s, the memory claim of Communism began to focus on the duty to remember the historical trauma of Communism in order to prevent its reoccurrence, on the need to restore the human dignity of victims, and on the moral lesson that the memory of Communism is supposed to transmit. Since in the political context of European enlargement refusing to cultivate the memory of the Holocaust was highly illegitimate, the memory of Communism was born as the "twin brother" of Holocaust memory. In the transnational political context, the Europeanized memory of Communism produced a legitimate differentia specifica of the newcomers in relation to old member states. It has been publicly reclaimed as an Eastern European experience in relation to universal Holocaust memory perceived as Western. At the same time, the idea of "double victimhood" served as a symbolic resource in the ongoing transnational competition of victims' "historical experiences," differing mainly in terms of geographical reference. Memorial museums of Communism played a crucial role in this localization, since they served as legitimate evidence of the fact that here Communist terror also took place.

Memorial museums of Communism can be considered as laboratories where the main elements of the discursive repertoire applied in post-accession political debates about Europe were elaborated in a pan-European way. Most importantly, they create, visualize, and materialize a political space which is organized according to the equality of victimhood. What is at stake in this binary space is the legitimate comparison of the two symbols of evil in history. It is against the background of the space of equal victims that one of the most important arguments of challenging the uniqueness claim of the Holocaust is formulated: the West applies a double standard when recognizing and restoring the dignity of the victims of Nazism, while denying the same of victims of Communism. It is decisive to the post-accession European debates about historical legacies that the argumentative repertoire of challenging the uniqueness of the Holocaust by the memory claim of Communism had been elaborated before the accession of the respective countries in 2004: based on a pan-European anti-Communist discourse of historical revisionism and according to the norms imposed as symbolic criteria of accession. As a result, political struggles for the definition of Europe took the form of a mimetic competition of the victims, in which two similar, depoliticized, and abstract images of the past clashed. The great debate on European history happened to be nothing more than a "comfortable controversy," in which "Each side is so palpably wrong about so many major issues that the other cannot help but feel that it must, in turn, be right" (Snyder 2013, 88). 


\section{Funding}

This research project was supported by the Collegium de Lyon, where the author worked as an invited researcher during the academic year 2015-2016 and National Research, Development and Innovation Office (NKFIH, PD 115736).

\section{Notes}

1. See historian Horia Patapievici's argument (quoted in Laignel-Lavastine 2004, 191 or Luik 2008).

2. http://okupacijasmuzejs.lv/en/about-museum/mission-and-history. Accessed 14 November 2016.

3. This and subsequent citations from the website: http://www.okupatsioon.ee/vanaweb/en/who-weare/154-avamiskoned. Accessed 14 November 2016.

4. See the text at http://2001-2006.orbanviktor.hu/; video recording at https://www.youtube.com/ watch?v=DAQpHYU3m3s. Accessed 14 November 2016.

5. http://www.okupatsioon.ee/index.php/et/home/whoweare. Accessed 14 November 2016.

6. http://www.okupatsioon.ee/index.php/et/home/whoweare. Accessed 14 November 2016.

7. news.err.ee (25 February 2016). Accessed 14 November 2016.

\section{References}

Ablonczy, Bálint. 2012. "Békévé oldja?" válasz.hu, March 19. http://valasz.hu/reflektor/bekeveoldja-46948.

Akinsha, Konstantin. 2006. "Bringing Communism to the Museum." Report. Magazine for Arts and Civil Society in Eastern- and Central Europe. http://www.redost.com/1/texts/comments/ bringing-communism-to-the-museum/.

Apor, Péter. 2012. "Master Narratives of Contemporary History in Eastern European National Museums." In Great Narratives of the Past. Traditions and Revisions in National Museums Conference Proceedings from EuNaMus, European National Museums. Identity Politics, the Uses of the Past and the European Citizen, Paris, June 29-July 1 and November 25-26, 2011, 569-585. Linköping: Linköping University Electronic Press. http://www.ep.liu.se/ecp/ contents. asp?issue $=078 \&$ volume $=$.

Aronson, Ronald. 2003. “Communism's Posthumous Trial.” History and Theory 42 (2): 222-245.

Assmann, Aleida. 2011. "Europe's Divided Memory.” In Clashes in European Memory: The Case of Communist Repression and the Holocaust, edited by Muriel Blaive, Christian Gerbel, and Thomas Lindenberger, 270-280. Innsbruck: Studien Verlag.

Bădică, Simina. 2013. Curating Communism. A Comparative History of Museological Practices in Post-War (1946-1958) and Post-Communist Romania. Budapest: Central European University.

Besançon, Alain. 1998. Le malheur du siècle: sur le communisme, le nazisme et l'unicité de la Shoah. Paris: Fayard.

Bielecki, Czesław, ed. 2003. SocLand: Muzeum Komunizmu $($ W Budowie $)=$ Museum of Communism (under Constraction). Warszawa: Volumen.

Bonnard, Pascal, and Markus Meckl. 2007. "La gestion du double passé nazi et soviétique en Lettonie: impasses et dépassement de la concurrence entre mémoires du Goulag et d'Auschwitz." In L'Europe et ses passés douloureux, edited by Georges Mink, Laure Neumayer, and Pascal Bonnard, 169-180. Paris: La Découverte.

Bourdieu, Pierre. 1985. "The Social Space and the Genesis of Groups." Theory and Society 14 (6): 723-744.

Budryte, Dovile. 2005. Taming Nationalism? Political Community Building in the Post-Soviet Baltic States. Aldershot: Ashgate.

Burch, Stuart, and Ulf Zander. 2010. "Preoccupied by the Past. The Case of Estonia's Museum of Occupations." Scandia: Tidskrift För Historisk Forskning 74 (2): 53-73.

Calligaro, Oriane. 2015. "Legitimation Through Remembrance? The Changing Regimes of Historicity of European Integration." Journal of Contemporary European Studies 23 (3): 330-343.

Chaumont, Jean-Michel. 1997. La concurrence des victimes: génocide, identité, reconnaissance. Paris: La Découverte. 
Christofferson, Michael Scott. 2004. French Intellectuals Against the Left: The Antitotalitarian Moment of the 1970's. New York: Berghahn Books.

Courtois, Stéphane. 1997. "Les Crimes Du Communisme." In Le Livre Noir du Communisme: Crimes, Terreur, Répression, edited by Stéphane Courtois, Nicolas Werth, Jean-Louis Panné, Andrzej Paczkowski, Karel Bartosek, and Jean-Louis Margolin, 9-40. Paris: Laffont.

Courtois, Stéphane. 2003. Courtois la Sighet. Edited by Ioana Boca and Romulus Rusan. Bucharest: Fundația Academica Civică.

Cristea, Gabriela, and Simina Radu-Bucurenci. 2008. "Raising the Cross. Exorcising Romania's Communist Past in Museums, Memorials and Monuments." In Past for the Eyes: East European Representations of Communism in Cinema and Museums after 1989, edited by Péter Apor and Oksana Sarkisova, 275-305. Budapest: CEU Press.

Denis, Juliette. 2011. "Entretiens avec les directeurs du Musée juif et du Musée de l'occupation de Riga, les 29 et 30 avril 2011, à Riga, Lettonie." The Journal of Power Institutions in PostSoviet Societies. Pipss.org, June 12. http://pipss.revues.org/3890.

Frazon, Zsófia, and Zsolt K. Horváth. 2002. "A Megsértett Magyarország. A Terror Háza Mint Tárgybemutatás, Emlékmú És Politikai Rítus.” Regio - Kisebbség, Politika, Társadalom 13 (4): 303-347.

Gergely, Márton. 2002. "Magyar Múltfeltárás: Terror Háza: Tettesek a Falon.” Magyar Narancs 44. http://magyarnarancs.hu/belpol/magyar_multfeltaras_terror_haza_tettesek_a_falon-61032.

Gliszczyńska-Grabias, A. 2016. "Communism Equals or Versus Nazism? Europe's Unwholesome Legacy in Strasbourg." East European Politics \& Societies 30 (1): 74-96.

Goldman, Natasha. 2006. "Israeli Holocaust Memorial Strategies at Yad Vashem: From Silence to Recognition." Art Journal 65 (2): 102-123.

Hein, Hilde S. 2000. The Museum in Transition: A Philosophical Perspective. Washington, DC: Smithsonian Books.

Jouhanneau, Cécile, and Laure Neumayer. 2014. "Introduction." Revue D'études Comparatives EstOuest 45 (3-4): 5-19.

Kundera, Milan. 1983. "Un Occident kidnappé." Le Débat 27: 3-23.

Laignel-Lavastine, Alexandra. 2004. "Fascism and Communism in Romania: The Comparative Stakes and Uses." In Stalinism and Nazism. History and Memory Compared, edited by Henry Rousso and Richard Golsan, 157-193. Lincoln: University of Nebraska Press.

Leggewie, Claus. 2010. "Equally Criminal? Totalitarian Experience and European Memory.”Tr@nsit Online, April 27. http://www.iwm.at/read-listen-watch/transit-online/equally-criminal/.

Linenthal, Edward. 2001. Preserving Memory: The Struggle to Create America's Holocaust Museum. New York: Columbia University Press.

Luik, Jüri. 2008. "Our Duty.” Diplomaatia 54: 16-18.

Macdonald, Sharon. 2013. Memorylands: Heritage and Identity in Europe Today. London: Routledge.

Maier, Charles S. 1993. "A Surfeit of Memory? Reflections on History, Melancholy and Denial." History and Memory 5 (2): 136-152.

Main, Izabella. 2008. "How Is Communism Displayed? Exhibitions and Museums of Communism in Poland." In Past for the Eyes: East European Representations of Communism in Cinema and Museums after 1989, edited by Oksana Sarkisova and Péter Apor, 371-400. Budapest: CEU Press.

Mälksoo, Maria. 2014. "Criminalizing Communism: Transnational Mnemopolitics in Europe." International Political Sociology 8 (1): 82-99.

Mark, James. 2008. "Containing Fascism. History in Post-Communist Baltic Occupation and Genocide Museums." In Past for the Eyes: East European Representations of Communism in Cinema and Museums after 1989, edited by Oksana Sarkisova and Péter Apor, 335-369. Budapest: CEU Press.

Mark, James. 2010. The Unfinished Revolution: Making Sense of the Communist Past in CentralEastern Europe. New Haven, CT: Yale University Press.

Neumayer, Laure. 2015. "Integrating the Central European Past into a Common Narrative: The Mobilizations Around the 'Crimes of Communism' in the European Parliament." Journal of Contemporary European Studies 23 (3): 344-363.

Novick, Peter. 1999. The Holocaust in American Life. New York: Houghton Mifflin.

Onken, Eva-Clarita. 2007. "The Politics of Finding Historical Truth: Reviewing Baltic History Commissions and Their Work." Journal of Baltic Studies 38 (1): 109-116. 
Probst, Lothar. 2003. "Founding Myths in Europe and the Role of the Holocaust." New German Critique 90: 45-58.

Rényi, András. 2003. "A retorika terrorja. A Terror Háza mint esztétikai probléma." Élet és Irodalom 47 (27): 15-17.

Rousso, Henry. 2011. "The History of Memory. Brief Reflections on an Overloaded Field." In Clashes in European Memory: The Case of Communist Repression and the Holocaust, edited by Muriel Blaive, Christian Gerbel, and Thomas Lindenberger, 231-238. Innsbruck: StudienVerlag.

Sarkisova, Oksana, and Péter Apor, eds. 2008. Past for the Eyes: East European Representations of Communism in Cinema and Museums After 1989. Budapest: CEU Press.

Schmidt, Mária. 2003a. “A Terror Háza Múzeum Első Éve.” In Egyazon Mércével: A Visszaperelt Történelem, 176-206. Budapest: XX. század intézet kiadó.

Schmidt, Mária. [1999] 2003b. “'Holocaustok' a Huszadik Században.” In Egyazon Mércével: A Visszaperelt Történelem, 10-16. Budapest: XX. század intézet kiadó.

Schmidt, Mária, ed. 2003c. Terror Háza, Andrássy Út 60 [House of Terror, Andrássy Út 60]. Budapest: Public Endowment for Research in Central and East-European History and Society.

Snyder, Timothy. 2013. "Commemorative Causality." Modernism/modernity 20 (1): 77-93.

Todorov, Tzvetan. 1995. Les abus de la mémoire. Paris: Arléa.

Todorov, Tzvetan. 2000. Mémoire du mal, tentation du bien: enquête sur le siècle. Paris: Laffont.

Weinberg, Jeshajahu. 1994. "A Narrative History Museum.” Curator: The Museum Journal 37 (4): 231-239.

Zombory, Máté. 2012. Maps of Remembrance: Space, Belonging and Politics of Memory in Eastern Europe. Budapest: L'Harmattan. 